\title{
Estimation of VECM Parameter Using Bayesian Approach: An Application to Analysis of Macroeconomic Variables
}

\author{
Meilina Retno Hapsari ${ }^{1}$, Suci Astutik ${ }^{2}$, Loekito Adi Soehono ${ }^{3}$ \\ ${ }^{1,2,3}$ Department of Statistics, Faculty of Mathematics and Natural Sciences, Brawijaya University, Indonesia \\ Correspondence: Meilina Retno Hapsari, Department of Statistics, Faculty of Mathematics and Natural Sciences, \\ Brawijaya University, Indonesia
}

Received: September 16, 2020

Accepted: October 20, 2020 Online Published: October 25, 2020

doi:10.5539/ijsp.v9n6p113

URL: https://doi.org/10.5539/ijsp.v9n6p113

\begin{abstract}
This study uses the Bayesian approach to estimate Vector Error Correction Model (VECM). The aim of this study is to analyze the relationship between macroeconomic variables in Indonesia. To analyze the best method to influence government targets or policies on economic growth by studying the relationships of many macroeconomic variables. Previous studies in analyzing the relationship between macroeconomic variables with VECM analysis, using the Maximum Likelihood Estimation. However, this estimation method cannot solve the problem of overparameterization in VECM model. The variables used in this study are six macroeconomic variables in Indonesia in 2010 quarter 1 to 2019 quarter 4 are GDP, the money supply, exchange rate of rupiah to US dollar, exports, imports and interest rates. The number of data in this study is less than the number of estimated parameters causing overparameterization problems. Therefore, this study uses the Bayesian parameter estimation method to avoid overparameterization problems in economic data. The model obtained from this study is the $\operatorname{BVECM}(3)$ and it has been proven that the model is suitable (the model diagnostic test). Based on the parameter estimation results of BVECM(3), the significant variables affecting GDP are GDP itself, the money supply, exchange rate of rupiah to US Dollar, exports, imports and the interest rate for Bank Indonesia Certificates. In addition, there is a two-way relationship that affects each other, namely the relationship between GDP and the money supply, exports and imports, exports and interest rates, and between imports and interest rates.
\end{abstract}

Keywords: VECM, Bayesian, BVECM, macroeconomic

\section{Introduction}

In the field of economics, multivariate time series analysis is commonly used, one of which is the Vector Error Correction Model (VECM) or restricted VAR model developed by Johansen and Julius (Enders, 2015). VECM is an analysis of economic variables that has a long term and a short term for data which is not stationary (Gujarati \& Porter, 2009). The variables in VECM have a long-term relationship and the long term relationship is defined as cointegration. The most commonly used parameter estimation techniques for VECM are Least Square and Maximum Likelihood Estimation. These methods have the advantage that they are easier to apply for a large number of observations.

Several previous studies have been conducted to analyze the relationship between macroeconomic variables in Indonesia using VECM analysis with Maximum Likelihood Estimation, such as Basuki \& Prawoto (2018) and Sinay (2014). However, there is a drawback of the classical parameter estimation method to produce the best (unbiased) parameter estimation because the data used must meet the multivariate normal assumptions and the sample size ranges from 100-300 (Byrne, 2013). In VAR and VECM models, problems often occur, when there are too many parameters to be estimated and the number of data is less than the estimated parameters (overparameterization), then the forecasting capacity is weak because the model is not suitable. The classical prediction method cannot solve the overparameterization problem. Therefore, the Bayesian parameter estimation method in the VAR model is to avoid the problem of overparameterization in economic data Tahir (2014).

The Bayesian approach to cointegration has the advantage of producing a probability distribution for each parameter which is valid for all sample sizes and does not require multivariate normal assumptions of the data (Villani, 2005). The Bayesian method can estimate parameters better than other classical methods such as Least Square and Maximum Likelihood Estimation because apart from using sample data information, it also utilizes other previously available information (prior distribution) (Pereira, 1999). Bayesian approach is used to analyze economic problems that have a long-term relation or cointegration relationship. This is called Bayesian Vector Error Correction Model (BVECM). 
BVECM has been discussed in Villani (2005) and Karlsson (2013), which discussed the prior, posterior and Gibbs Sampler distributions, but these research only provide a theoretical basis and has not been applied to a case study.

In this study, we implement a VECM with the Bayesian approach. This study aims to show the relationship between macroeconomic variables between the money supply, exchange rate of rupiah to US Dollar, exports, imports, interest rates from Bank Indonesia Certificates and GDP in Indonesia. This research is also important in the economic areas because it can analyze the best way to influence government targets or policies on economic growth. Economic growth in Indonesia can be seen from the variable of Gross Domestic Product (GDP). Based Keynesian theory of the equation $\mathrm{Y}=\mathrm{C}+\mathrm{G}+\mathrm{I}+(\mathrm{X}-\mathrm{M})$ that the money supply, exports and imports will affect GDP (Mankiw, 2009). Economic growth can also be seen from macroeconomic variables other than GDP, namely the money supply, interest rates, exports, exchange rate of rupiah to US Dollar and others because GDP variables are also influenced by these macroeconomic variables (Syed \& Shaikh, 2013). GDP is affected by the exchange rate, exports and imports together. Rupiah exchange rates affect exports and imports (Machmud, 2016). GDP can also affect interest rates. An increase in GDP leads to an increase in interest rates (Amzal, 2016). The relationship studied in macroeconomics is a causal relationship between macroeconomic variables as a whole (Esen \& Bayrak, 2017; Mankiw, 2009).

\section{Method}

\subsection{Data}

The data used in this study are secondary data obtained from the Indonesian Central Bureau of Statistics (www.bps.go.id) and the website of Bank Indonesia (www.bi.go.id). The variables used in this study are six macroeconomic variables in Indonesia in 2010 quarter 1 to 2019 quarter 4, and the total sample size is 40. The macroeconomic variables to be analyzed are GDP at constant 2010 prices (GDP), the money supply in a broad sense (M2), exchange rate of rupiah to US Dollar (Kurs), total export revenue (Ex), total import revenue (Imp) and interest rates from Bank Indonesia Certificates (SBI). Data used from 2010 due to limited GDP data at constant prices. GDP at constant prices starting in 2010. So, the number of data in this study is less than the number of estimated parameters that causes overparameterization problems.

\subsection{Vector Error Correction Model}

The general form of VECM (p-1) where $\mathrm{p}$ is the lag of the endogenous variable with cointegration rank $\leq \mathrm{r}$ is as follows (Lutkepohl, 2005):

$$
\Delta \boldsymbol{Y}_{t}=\prod \boldsymbol{Y}_{t-1}+\boldsymbol{\Gamma}_{1} \Delta \boldsymbol{Y}_{t-1}+\cdots+\boldsymbol{\Gamma}_{p} \Delta \boldsymbol{Y}_{t-p+1}+\boldsymbol{\varepsilon}_{t}
$$

The first step that must be taken in VECM analysis is to test the stationarity of the data for each macroeconomic variable. According to Gujarati \& Porter (2009), the stationarity test can be done with the unit root test (Augmented Dickey Fuller Test). If the data is not stationary, it is necessary to differencing the data. After the data is stationary, it is necessary to determine the length of the lag by using several information criteria. According to Enders (2015), information criteria which is often used is the Akaike Information Criterion (AIC). The selected lag length can be determined through the minimum value of the AIC criteria. After obtaining the optimum lag length, a cointegration test is performed because cointegration is the main requirement of the VECM model. The cointegration test is done using the Johansen approach. The VECM model is structured if the cointegration rank (r) is greater than zero (Verbeek, 2017).

\subsection{Bayesian Vector Error Correction Model}

One of the alternative approaches to estimate parameters other than classical parameter estimation such as Least Square and Maximum Likelihood Estimation is the Bayesian method. There are several advantages to the Bayesian estimation method. First, the Bayesian method does not require the assumption of multivariate normality like other classical methods. Second, according to Villani (2005), Bayesian cointegration analysis is very useful because the Bayesian approach produces a distribution of the point estimates parameter used to construct the cointegration and produces a probability distribution for each parameter that is valid for all sample sizes. In addition, more information was obtained from the bayesian estimation of parameters (confidence interval, mean, mode and median). Third, the Bayesian method can be used to avoid the problem of overparameterization in economic data, as stated by Tahir (2014). The difference between the Bayesian approach and the classical approach is that the parameters in the Bayesian method are considered as random variables. Therefore, the prior distribution must be determined first and the researcher can choose the prior distribution based on the confidence of researchers, but it must be useful as initial information to estimate the VECM parameter.

The posterior distribution includes prior distribution and observational data information (Ntzoufras, 2009). The posterior distribution is proportional to the product of the likelihood function and the prior distribution. The likelihood function of the VECM is as follows 


$$
\begin{gathered}
L(\boldsymbol{D} \mid \boldsymbol{\Pi}, \boldsymbol{\Gamma}, \boldsymbol{\Sigma})=|\boldsymbol{\Sigma}|^{-T / 2} \exp \left(-\frac{1}{2} \operatorname{tr}\left[\boldsymbol{\Sigma}^{-\mathbf{1}}\left(\Delta \boldsymbol{Y}-\boldsymbol{\Pi}^{\prime} \boldsymbol{Y}_{-\mathbf{1}}-\boldsymbol{\Gamma} \Delta \boldsymbol{X}\right)^{\prime}\left(\Delta \boldsymbol{Y}-\boldsymbol{\Pi}^{\prime} \boldsymbol{Y}_{-\mathbf{1}}-\boldsymbol{\Gamma} \Delta \boldsymbol{X}\right)\right]\right) \\
L(\boldsymbol{D} \mid \boldsymbol{\Pi}, \boldsymbol{\Gamma}, \boldsymbol{\Sigma})=|\boldsymbol{\Sigma}|^{-T / 2} \exp \left(-\frac{1}{2} \operatorname{tr}\left[\boldsymbol{\Sigma}^{-\mathbf{1}} \boldsymbol{E}^{\prime} \boldsymbol{E}\right]\right)
\end{gathered}
$$

The joint posterior distribution of the VECM parameters is as follows

$$
f(\boldsymbol{\Pi}, \boldsymbol{\Gamma}, \boldsymbol{\Sigma} \mid \boldsymbol{D}) \propto L(\boldsymbol{D} \mid \boldsymbol{\Pi}, \boldsymbol{\Gamma}, \boldsymbol{\Sigma}) \times f(\boldsymbol{\Pi}, \boldsymbol{\Gamma}, \boldsymbol{\Sigma})
$$

Then, estimating the parameters of the Vector Error Correction Model with a Bayesian approach, using the Gibbs Sampler simulation. The Gibbs Sampler algorithm uses a conditional posterior distribution. Briefly, the steps for the Gibbs Sampler algorithm (Karlsson, 2013) are:

1. Set the initial value for each parameter

$$
\boldsymbol{\theta}^{(0)}=\left(\boldsymbol{\Sigma}^{(0)}, \boldsymbol{\Pi}^{(0)}, \boldsymbol{\Gamma}^{(0)}\right)
$$

2. After determining the initial value, the process of generating new parameter from the full conditional posterior is carried out.

$$
\begin{aligned}
& \varepsilon_{11}^{(1)} \sim f\left(\varepsilon_{11} \mid \varepsilon_{12}^{(0)}, \ldots, \varepsilon_{k k}^{(0)}, \Pi_{11}^{(0)}, \Pi_{12}^{(0)}, \ldots, \Pi_{k k}^{(0)}, \Gamma_{11}^{(0)}, \Gamma_{12}^{(0)}, \ldots, \Gamma_{k k}^{(0)}, \boldsymbol{D}\right) \\
& \varepsilon_{12}^{(1)} \sim f\left(\varepsilon_{12} \mid \varepsilon_{11}^{(1)}, \ldots, \varepsilon_{k k}^{(0)}, \Pi_{11}^{(0)}, \Pi_{12}^{(0)}, \ldots, \Pi_{k k}^{(0)}, \Gamma_{11}^{(0)}, \Gamma_{12}^{(0)}, \ldots, \Gamma_{k k}^{(0)}, \boldsymbol{D}\right) \\
& \vdots \\
& \varepsilon_{k k}^{(1)} \sim f\left(\varepsilon_{k k} \mid \varepsilon_{11}^{(1)}, \varepsilon_{12}^{(1)}, \ldots, \Pi_{11}^{(0)}, \Pi_{12}^{(0)}, \ldots, \Pi_{k k}^{(0)}, \Gamma_{11}^{(0)}, \Gamma_{12}^{(0)}, \ldots, \Gamma_{k k}^{(0)}, \boldsymbol{D}\right) \\
& \Pi_{11}^{(1)} \sim f\left(\Pi_{11} \mid \varepsilon_{11}^{(1)} \varepsilon_{12}^{(1)}, \ldots, \varepsilon_{k k}^{(1)}, \Pi_{12}^{(0)}, \ldots, \Pi_{k k}^{(0)}, \Gamma_{11}^{(0)}, \Gamma_{12}^{(0)}, \ldots, \Gamma_{k k}^{(0)}, \boldsymbol{D}\right) \\
& \Pi_{12}^{(1)} \sim f\left(\Pi_{12} \mid \varepsilon_{11}^{(1)}, \varepsilon_{12}^{(1)} \ldots, \varepsilon_{k k}^{(1)}, \Pi_{11}^{(1)}, \ldots, \Pi_{k k}^{(0)}, \Gamma_{11}^{(0)}, \Gamma_{12}^{(0)}, \ldots, \Gamma_{k k}^{(0)}, \boldsymbol{D}\right) \\
& \vdots \\
& \Gamma_{11}^{(1)} \sim f\left(\Gamma_{11} \mid \varepsilon_{11}^{(1)}, \varepsilon_{12}^{(1)}, \ldots, \varepsilon_{k k}^{(1)}, \Pi_{11}^{(1)}, \Pi_{12}^{(1)}, \ldots, \Pi_{k k}^{(1)}, \Gamma_{12}^{(0)}, \ldots, \Gamma_{k k}^{(0)}, \boldsymbol{D}\right) \\
& \Gamma_{12}^{(1)} \sim f\left(\Gamma_{12} \mid \varepsilon_{11}^{(1)}, \varepsilon_{12}^{(1)}, \ldots, \varepsilon_{k k}^{(1)}, \Pi_{11}^{(1)}, \Pi_{12}^{(1)}, \ldots, \Pi_{k k}^{(1)}, \Gamma_{11}^{(1)}, \ldots, \Gamma_{k k}^{(0)}, \boldsymbol{D}\right) \\
& \vdots \\
& \Gamma_{k k}^{(1)} \sim f\left(\Gamma_{k k} \mid \varepsilon_{11}^{(1)}, \varepsilon_{12}^{(1)}, \ldots, \varepsilon_{k k}^{(1)}, \Pi_{11}^{(1)}, \Pi_{12}^{(1)}, \ldots, \Pi_{k k}^{(1)}, \Gamma_{11}^{(1)}, \Gamma_{12}^{(1)}, \ldots, \boldsymbol{D}\right)
\end{aligned}
$$

3. After forming $\left(\Sigma^{(t)}, \boldsymbol{\Pi}^{(t)}, \boldsymbol{\Gamma}^{(t)}\right)$ then stored as a set of values that will be used for generation in the iteration to $(\mathrm{t}+1)$ of the algorithm,

4. Perform steps 1 to 3 as many iterations as desired. The average value of the simulation results for each element in the parameter is then used as parameter estimator.

For simplification, the common process using $i, j, k$ for each parameter of BVECM is as follows:

1. Set the initial value for each parameter

$$
\boldsymbol{\theta}^{(i)}=\left(\boldsymbol{\Sigma}^{(i)}, \boldsymbol{\Pi}^{(i)}, \boldsymbol{\Gamma}^{(i)}\right)
$$

2. After determining the initial value, the process of generating new parameter from the full conditional posterior is carried out.

$$
\begin{aligned}
& \varepsilon_{j 1}^{(i+1)} \sim f\left(\varepsilon_{j 1} \mid \varepsilon_{j 2}^{(i)}, \ldots, \varepsilon_{j j}^{(i)}, \Pi_{j 1}^{(i)}, \Pi_{j 2}^{(i)}, \ldots, \Pi_{j j}^{(i)}, \Gamma_{j 1}^{(i)}, \Gamma_{j 2}^{(i)}, \ldots, \Gamma_{j j}^{(i)}, \boldsymbol{D}\right) \\
& \vdots \\
& \varepsilon_{j j}^{(i+1)} \sim f\left(\varepsilon_{j j} \mid \varepsilon_{j 1}^{(i+1)}, \varepsilon_{j 2}^{(i+1)}, \ldots, \Pi_{j 1}^{(i)}, \Pi_{j 2}^{(i)}, \ldots, \Pi_{j j}^{(i)}, \Gamma_{j 1}^{(i)}, \Gamma_{j 2}^{(i)}, \ldots, \Gamma_{k k}^{(i)}, \boldsymbol{D}\right) \\
& \Pi_{j 1}^{(i+1)} \sim f\left(\Pi_{j 1} \mid \varepsilon_{j 1}^{(i+1)}, \varepsilon_{j 2}^{(i+1)} \ldots, \varepsilon_{j j}^{(i+1)}, \Pi_{j 2}^{(i)}, \ldots, \Pi_{j j}^{(i)}, \Gamma_{j 1}^{(i)}, \Gamma_{j 2}^{(i)}, \ldots, \Gamma_{j j}^{(i)}, \boldsymbol{D}\right) \\
& \vdots \\
& \Pi_{j j}^{(1+1)} \sim f\left(\Pi_{j j} \mid \varepsilon_{j 1}^{(i+1)}, \varepsilon_{j 2}^{(i+1)} \ldots, \varepsilon_{j j}^{(i+1)}, \Pi_{j 1}^{(i+1)}, \Pi_{j 2}^{(i+1)}, \ldots, \Gamma_{j 1}^{(i)}, \Gamma_{j 2}^{(i)}, \ldots, \Gamma_{j j}^{(i)}, \boldsymbol{D}\right)
\end{aligned}
$$




$$
\begin{aligned}
& \Gamma_{j 1}^{(i+1)} \sim f\left(\Gamma_{j 1} \mid \varepsilon_{j 1}^{(i+1)}, \varepsilon_{j 2}^{(i+1)} \ldots, \varepsilon_{j j}^{(i+1)}, \Pi_{j 1}^{(i+1)}, \Pi_{j 2}^{(i+1)}, \ldots, \Pi_{j j}^{(i+1)}, \Gamma_{j 2}^{(i)}, \ldots, \Gamma_{j j}^{(i)}, \boldsymbol{D}\right) \\
& \vdots \\
& \Gamma_{j j}^{(i+1)} \sim f\left(\Gamma_{j j} \mid \varepsilon_{j 1}^{(i+1)}, \varepsilon_{j 2}^{(i+1)} \ldots, \varepsilon_{j j}^{(i+1)}, \Pi_{j 1}^{(i+1)}, \Pi_{j 2}^{(i+1)}, \ldots, \Pi_{j j}^{(i+1)}, \Gamma_{j 1}^{(i+1)}, \Gamma_{j 2}^{(i+1)}, \ldots, \Gamma_{j j}^{(i)}, \boldsymbol{D}\right)
\end{aligned}
$$

3. After forming $\left(\boldsymbol{\Sigma}^{(t)}, \boldsymbol{\Pi}^{(t)}, \boldsymbol{\Gamma}^{(t)}\right)$ then stored as a set of values that will be used for generation in the iteration to $(\mathrm{t}+1)$ of the algorithm,

4. Perform steps 1 to $3 k$ times, as many iterations as desired

The next step in the BVECM approach is to test the convergence of the estimated parameters. Examination of the convergence of simulation results using the trace plot and density plot. Convergence check is used to find out whether the generated observations match the posterior distribution. Convergence checks can be done with trace plots and density plots between observations that have been raised (Ntzoufras, 2009). If convergence has not been fulfilled, the iteration needs to be increased. Then, to test the significance of BVECM parameters using the Credible Interval with a lower limit of the percentile of $2.5 \%$ and an upper limit of the percentile of $97.5 \%$ (Ntzoufras, 2009). The criteria for the null hypothesis is rejected, if the credible interval does not contain zero values

\subsection{Diagnostic Model}

The diagnostic model is to test whether the model is feasible. Diagnostic model tests performed on the VECM model are normality of the residual and non-autocorrelation of the residual. The residual normality test used the multivariate normality test with the skewness and kurtosis test with the chi-square distribution approach. The autocorrelation test uses the Portmanteau Autocorrelation test or the Ljung Box Test (Lutkepohl, 2007).

The test statistic used is the statistic $Q_{p}$ :

$$
Q_{p}=T \sum_{i=1}^{p} \operatorname{tr}\left(\widehat{\boldsymbol{C}}_{i}^{\prime} \widehat{\boldsymbol{C}}_{0}^{-1} \widehat{\boldsymbol{C}}_{i} \widehat{\boldsymbol{C}}_{0}^{-1}\right)
$$

where $\hat{C}_{i}=T \sum_{t=i+1}^{p} \hat{\boldsymbol{\varepsilon}}_{t} \widehat{\boldsymbol{\varepsilon}}_{t-i}^{\prime}, \hat{C}_{0}=T \sum_{t=i+1}^{p} \widehat{\boldsymbol{\varepsilon}}_{t} \widehat{\boldsymbol{\varepsilon}}_{t}^{\prime}$ and $\hat{\boldsymbol{\varepsilon}}_{t}$ is an estimated residual. $Q_{p}$ has $\chi^{2}$ distribution with degrees of freedom is $k^{2} p$. If the $\mathrm{p}$-value of the $Q_{p}$ statistics is greater than $\alpha$, then the hypothesis $\mathrm{H}_{0}$ is accepted and it means that there is no autocorrelation in residual.

\section{Results}

The first step to be taken in time series analysis is to test the stationarity of the data for each macroeconomic variable. The stationarity of the data can be tested using the Augmented Dickey Fuller (ADF) method (Gujarati \& Porter, 2009). Following is the output of each variable can be seen in Table 1.

Table 1. Augmented Dickey-Fuller (ADF) Test Result

\begin{tabular}{ccccc}
\hline Variable & \multicolumn{2}{c}{ Level } & \multicolumn{2}{c}{ Difference } \\
\cline { 2 - 5 } & t-statistic & p-value & t-statistic & p-value \\
\hline LnM2 & -1.3878 & 0.8137 & -4.3152 & 0.01 \\
LnKurs & -0.8707 & 0.9452 & -2.6742 & 0.09143 \\
LnEks & -2.1501 & 0.2664 & -3.9698 & 0.01 \\
LnImp & -1.8728 & 0.3661 & -2.6547 & 0.09423 \\
LnSBI & -1.3833 & 0.5419 & -3.5554 & 0.0141 \\
LnPDB & -2.2001 & 0.4949 & -19.5379 & 0.01 \\
\hline
\end{tabular}

Table 1 on the level data, shows that six macroeconomic variables are not stationary at the significant levels of $10 \%$, because p-value $>0.1$. Therefore it is necessary to do data differencing so that the data becomes stationary and it is necessary to test the stationarity of the data again. Based on the results of the data stationarity test on differencing data, it is shown that all six variables have p-values of less than $\alpha(0.1)$, so all variables are stationary at the $10 \%$ significant level. It can be concluded that the six macroeconomic variables are stationary in the first differencing data or have the same integration order, namely I (1) (Cryer \& Chan, 2008). The optimum lag of the VECM model was selected using the Akaike Information Criteria (AIC). The optimum lag test results are shown in Table 2.

Table 2. The Optimum Lag Test Result

\begin{tabular}{cc}
\hline Lag & AIC \\
\hline 1 & -41.1350 \\
2 & -43.6769 \\
3 & -45.3296 \\
4 & -46.8697 \\
\hline
\end{tabular}


Based on these results, the optimum model is at lag 4 because the AIC value on lag 4 is the minimum compared to the AIC value on the other lags. Then the cointegration test was carried out using the Johansen test (Verbeek, 2017). Table 3 shows the results of the cointegration test.

Table 3. Cointegration Test Result

\begin{tabular}{ccccc}
\hline Hypothesis & Trace Statistic & Critical Value 10\% & Critical Value 5\% & Critical Value 1\% \\
\hline $\mathrm{r}=0$ & 237.94 & 85.18 & 90.39 & 104.20 \\
$\mathrm{r} \leq 1$ & 133.74 & 66.49 & 70.60 & 78.87 \\
$\mathrm{r} \leq 2$ & 77.58 & 45.23 & 48.28 & 55.43 \\
$\mathrm{r} \leq 3$ & 39.49 & 28.71 & 31.52 & 37.22 \\
$\mathrm{r} \leq 4$ & 10.85 & 15.66 & 17.95 & 23.52 \\
$\mathrm{r} \leq 5$ & 0.20 & 6.50 & 8.18 & 11.65
\end{tabular}

Based on Table 3, it can be seen that the value of the trace statistics for the rank 1 hypothesis is 133.74 , which is greater than the critical value at $\alpha=10 \%, 5 \%$ and $1 \%$, so the decision to reject $\mathrm{H}_{0}$ is obtained. This means that the cointegration rank is more than 1 , and then it is necessary to continue the cointegration test for the next hypothesis. In the rank 4 hypothesis test, the trace statistic value is 10.85 . The trace statistic value is less than the critical value at $\alpha=$ $10 \%, 5 \%$ and $1 \%$, so the decision is to accept $\mathrm{H}_{0}$. Thus, based on this analysis, it can be concluded that the results of the cointegration test indicate that there are maximum of 4 cointegration equations. This finding explains that among the variables of GDP, the money supply, exchange rate of rupiah to US Dollar, exports, imports, and interest rates on Bank Indonesia Certificates have similar movement patterns and stability in long-term equilibrium. In each short-term period, all variables adjust to each other to achieve long-term equilibrium.

Based on the previous analysis, it is concluded that the macroeconomic variable relationship model in this study follows the BVECM(3). This model is obtained from the general model VECM(p-1) which is described in equation (1), where $\mathrm{p}$ is the optimum lag. Parameter estimation using the Gibbs Sampler simulation with the iteration of 500 samples to get convergent results. The results of the BVECM parameter estimation in this study can be summarized in Table 4 . In Table 4 for each variable, there are three lines. Line 1 is the average parameter values, line 2 is the lower limit of credible intervals and line 3 is the upper limit of credible intervals. ECT is a cointegration parameter of the BVECM model, which shows the speed of adjustment to achieve equilibrium from short to long term.

Table 4. Parameter Estimation Result of BVECM

\begin{tabular}{|c|c|c|c|c|c|c|}
\hline Variable & M2 & Kurs & Eks & Imp & SBI & GDP \\
\hline ECT1 & $\begin{array}{l}0.00299 \\
(-0.15525, \\
0.16843)\end{array}$ & $\begin{array}{l}-0.00094 \\
(-0.16399, \\
0.15825)\end{array}$ & $\begin{array}{l}-0.00049 \\
(-0.15968, \\
0.15062)\end{array}$ & $\begin{array}{l}-0.00195 \\
(-0.18117, \\
0.16518)\end{array}$ & $\begin{array}{l}-0.00098 \\
(-0.16778, \\
0.14827)\end{array}$ & $\begin{array}{l}0.00222 \\
(-0.15156, \\
0.16423)\end{array}$ \\
\hline ECT2 & $\begin{array}{l}-0.00473 \\
(-0.17812, \\
0.17422) \\
\end{array}$ & $\begin{array}{l}0.00431 \\
(-0.15901, \\
0.19072) \\
\end{array}$ & $\begin{array}{l}-0.00278 \\
(-0.19702, \\
0.17485) \\
\end{array}$ & $\begin{array}{l}0.00595 \\
(-0.16812, \\
0.19588)\end{array}$ & $\begin{array}{l}-0.01287 \\
(-0.20868, \\
0.15787) \\
\end{array}$ & $\begin{array}{l}-0.00487 \\
(-0.18641, \\
0.16978)\end{array}$ \\
\hline ECT3 & $\begin{array}{l}-0.00314 \\
(-0.18529, \\
0.18008)\end{array}$ & $\begin{array}{l}0.00250 \\
(-0.17014, \\
0.18678) \\
\end{array}$ & $\begin{array}{l}0.00525 \\
(-0.18763, \\
0.17771) \\
\end{array}$ & $\begin{array}{l}0.00724 \\
(-0.18262, \\
0.20094)\end{array}$ & $\begin{array}{l}0.00462 \\
(-0.17131, \\
0.18887) \\
\end{array}$ & $\begin{array}{l}0.00254 \\
(-0.16372, \\
0.18074)\end{array}$ \\
\hline ECT4 & $\begin{array}{l}0.00116 \\
(-0.19460, \\
0.18349)\end{array}$ & $\begin{array}{l}0.00073 \\
(-0.18623, \\
0.17541)\end{array}$ & $\begin{array}{l}0.00315 \\
(-0.18028, \\
0.18603)\end{array}$ & $\begin{array}{l}-0.00283 \\
(-0.17582, \\
0.18520)\end{array}$ & $\begin{array}{l}0.00281 \\
(-0.16956, \\
0.18160)\end{array}$ & $\begin{array}{l}0.00085 \\
(-0.18244, \\
0.18268)\end{array}$ \\
\hline ECT5 & $\begin{array}{l}-0.00568 \\
(-0.19543, \\
0.19259)\end{array}$ & $\begin{array}{l}-0.00276 \\
(-0.21406, \\
0.18851)\end{array}$ & $\begin{array}{l}-0.00925 \\
(-0.20839, \\
0.17477)\end{array}$ & $\begin{array}{l}-0.00082 \\
(-0.17816, \\
0.17326)\end{array}$ & $\begin{array}{l}-0.00037 \\
(-0.20330 \\
0.20939)\end{array}$ & $\begin{array}{l}0.00448 \\
(-0.20801, \\
0.20182)\end{array}$ \\
\hline ECT6 & $\begin{array}{l}0.00093 \\
(-0.15882 \\
0.18633)\end{array}$ & $\begin{array}{l}-0.00224 \\
(-0.16815, \\
0.17900)\end{array}$ & $\begin{array}{l}-0.00175 \\
(-0.17908, \\
0.17961)\end{array}$ & $\begin{array}{l}-0.00366 \\
(-0.15868, \\
0.15881)\end{array}$ & $\begin{array}{l}0.00439 \\
(-0.16762, \\
0.15615)\end{array}$ & $\begin{array}{l}-0.00202 \\
(-0.15755, \\
0.15409)\end{array}$ \\
\hline M2(-1) & $\begin{array}{l}0.44656 \\
(0.23454 \\
0.67318)\end{array}$ & $\begin{array}{l}-0.15488 \\
(-0.37479, \\
0.04493)\end{array}$ & $\begin{array}{l}0.06494 \\
(-0.14577, \\
0.28040)\end{array}$ & $\begin{array}{l}-0.05705 \\
(-0.24619, \\
0.13483)\end{array}$ & $\begin{array}{l}0.03862 \\
(-0.15675, \\
0.24079)\end{array}$ & $\begin{array}{l}0.31995 \\
(0.11301, \\
0.52619)\end{array}$ \\
\hline
\end{tabular}




\begin{tabular}{|c|c|c|c|c|c|c|}
\hline M2(-2) & $\begin{array}{l}0.22197 \\
(0.03715 \\
0.40552)\end{array}$ & $\begin{array}{l}-0.04855 \\
(-0.23731, \\
0.14372) \\
\end{array}$ & $\begin{array}{l}-0.00061 \\
(-0.19654, \\
0.17081) \\
\end{array}$ & $\begin{array}{l}0.02832 \\
(-0.15914, \\
0.21271) \\
\end{array}$ & $\begin{array}{l}-0.07320 \\
(-0.27247, \\
0.11920) \\
\end{array}$ & $\begin{array}{l}0.00585 \\
(-0.20823, \\
0.19774) \\
\end{array}$ \\
\hline M2(-3) & $\begin{array}{l}0.16516 \\
(-0.02611, \\
0.35078)\end{array}$ & $\begin{array}{l}0.05944 \\
(-0.13018, \\
0.24946)\end{array}$ & $\begin{array}{l}-0.00620 \\
(-0.19228, \\
0.18757)\end{array}$ & $\begin{array}{l}0.01334 \\
(-0.18463 \\
0.20144)\end{array}$ & $\begin{array}{l}0.08198 \\
(-0.12615 \text {, } \\
0.27267)\end{array}$ & $\begin{array}{l}0.11278, \\
(-0.08413, \\
0.31413)\end{array}$ \\
\hline Kurs(-1) & $\begin{array}{l}-0.01586 \\
(-0.20868, \\
0.19507\end{array}$ & $\begin{array}{l}0.33231 \\
(0.14662 \\
0.56176)\end{array}$ & $\begin{array}{l}-0.01492 \\
(-0.21297, \\
0.19959)\end{array}$ & $\begin{array}{l}-0.04411 \\
(-0.22420, \\
0.14645) \\
\end{array}$ & $\begin{array}{l}0.04168 \\
(-0.16328, \\
0.24079)\end{array}$ & $\begin{array}{l}0.06384 \\
(-0.11338, \\
0.25570)\end{array}$ \\
\hline Kurs(-2) & $\begin{array}{l}-0.07083 \\
(-0.25487, \\
0.13206)\end{array}$ & $\begin{array}{l}0.01368 \\
(-0.17750, \\
0.22200)\end{array}$ & $\begin{array}{l}-0.06759 \\
(-0.25682 \\
0.12424)\end{array}$ & $\begin{array}{l}0.06094 \\
(-0.13374, \\
0.23742) \\
\end{array}$ & $\begin{array}{l}-0.15033 \\
(-0.34219, \\
0.03902)\end{array}$ & $\begin{array}{l}-0.00439 \\
(-0.18562, \\
0.19524) \\
\end{array}$ \\
\hline Kurs(-3) & $\begin{array}{l}0.58104 \\
(0.38884 \\
0.78402)\end{array}$ & $\begin{array}{l}-0.18406 \\
(-0.36629, \\
0.00265) \\
\end{array}$ & $\begin{array}{l}-0.11092 \\
(-0.29483, \\
0.07491) \\
\end{array}$ & $\begin{array}{l}0.17554 \\
(-0.02066, \\
0.38037) \\
\end{array}$ & $\begin{array}{l}0.13042 \\
(-0.05738, \\
0.33158) \\
\end{array}$ & $\begin{array}{l}-0.39161 \\
(-0.60031, \\
-0.15141)\end{array}$ \\
\hline Eks(-1) & $\begin{array}{l}0.58104 \\
(0.38884 \\
0.78402)\end{array}$ & $\begin{array}{l}0.41315 \\
(0.21726 \\
0.60392)\end{array}$ & $\begin{array}{l}-0.37965 \\
(-0.58575, \\
-0.18587) \\
\end{array}$ & $\begin{array}{l}0.09503 \\
(-0.10140, \\
0.28212) \\
\end{array}$ & $\begin{array}{l}0.03830 \\
(-0.16316, \\
0.24641) \\
\end{array}$ & $\begin{array}{l}2.77817 \\
(2.58468, \\
2.97578) \\
\end{array}$ \\
\hline Eks(-2) & $\begin{array}{l}-2.36228 \\
(-2.56878, \\
-3.26745) \\
\end{array}$ & $\begin{array}{l}-1.11404 \\
(-1.32485, \\
0.91886) \\
\end{array}$ & $\begin{array}{l}0.27643 \\
(0.08000 \\
0.47332) \\
\end{array}$ & $\begin{array}{l}-0.41878 \\
(-0.61398 \\
-0.2333) \\
\end{array}$ & $\begin{array}{l}0.04186 \\
(-0.15157, \\
0.21883) \\
\end{array}$ & $\begin{array}{l}0.05945 \\
(-0.12899, \\
0.27146) \\
\end{array}$ \\
\hline Eks(-3) & $\begin{array}{l}0.49699 \\
(0.30228 \\
0.68905)\end{array}$ & $\begin{array}{l}-0.19282 \\
(-0.36755, \\
-0.00463) \\
\end{array}$ & $\begin{array}{l}0.49351 \\
(0.31210 \\
0.68452) \\
\end{array}$ & $\begin{array}{l}-0.36556 \\
(-0.52760 \\
-0.18150) \\
\end{array}$ & $\begin{array}{l}-0.30917 \\
(-0.49206, \\
-0.11343)\end{array}$ & $\begin{array}{l}2.45771 \\
(2.27122, \\
2.66343) \\
\end{array}$ \\
\hline $\operatorname{Imp}(-1)$ & $\begin{array}{l}-3.46184 \\
(-3.65278 \\
-3.26745) \\
\end{array}$ & $\begin{array}{l}0.60392 \\
(0.40876 \\
0.77980)\end{array}$ & $\begin{array}{l}-0.04386 \\
(-0.23600, \\
0.13753)\end{array}$ & $\begin{array}{l}-0.13968 \\
(-0.37360 \\
0.06226)\end{array}$ & $\begin{array}{l}-0.25792 \\
(-0.46466, \\
-0.06730)\end{array}$ & $\begin{array}{l}4.23834 \\
(4.04322, \\
4.43077) \\
\end{array}$ \\
\hline $\operatorname{Imp}(-2)$ & $\begin{array}{l}0.32914 \\
(0.15406 \\
0.51153)\end{array}$ & $\begin{array}{l}-0.59287 \\
(-0.78045, \\
0.40719) \\
\end{array}$ & $\begin{array}{l}0.22459 \\
(0.05499 \\
0.41218) \\
\end{array}$ & $\begin{array}{l}-0.13464 \\
(-0.32604, \\
0.04225) \\
\end{array}$ & $\begin{array}{l}0.05839 \\
(-0.14010, \\
0.26051)\end{array}$ & $\begin{array}{l}-0.13352 \\
(-0.31565, \\
0.05372)\end{array}$ \\
\hline $\operatorname{Imp}(-3)$ & $\begin{array}{l}-0.17728 \\
(-0.35403, \\
-0.01281) \\
\end{array}$ & $\begin{array}{l}-0.17519 \\
(-0.36126, \\
0.05607) \\
\end{array}$ & $\begin{array}{l}0.48054 \\
(0.28499 \\
0.66212) \\
\end{array}$ & $\begin{array}{l}-0.15111 \\
(-0.35871, \\
0.03727) \\
\end{array}$ & $\begin{array}{l}-0.16643 \\
(-0.34875, \\
0.02858) \\
\end{array}$ & $\begin{array}{l}3.24043 \\
(3.02500, \\
3.45355)\end{array}$ \\
\hline SBI(-1) & $\begin{array}{l}-0.81032 \\
(-1.00778, \\
-0.62561) \\
\end{array}$ & $\begin{array}{l}0.66499 \\
(0.46769, \\
0.82816)\end{array}$ & $\begin{array}{l}-0.34653 \\
(-0.52941, \\
-0.16226)\end{array}$ & $\begin{array}{l}0.28913 \\
(0.11539 \\
0.47066) \\
\end{array}$ & $\begin{array}{l}0.37003 \\
(0.17392 \\
0.57974) \\
\end{array}$ & $\begin{array}{l}0.10985 \\
(-0.09694, \\
0.31247) \\
\end{array}$ \\
\hline SBI(-2) & $\begin{array}{l}-0.28764 \\
(-0.47963, \\
-0.09221) \\
\end{array}$ & $\begin{array}{l}0.74682 \\
(0.55042, \\
0.92446) \\
\end{array}$ & $\begin{array}{l}0.01075 \\
(-0.18055, \\
0.20765) \\
\end{array}$ & $\begin{array}{l}0.28269 \\
(0.07610, \\
0.46951) \\
\end{array}$ & $\begin{array}{l}0.02915 \\
(-0.17424, \\
0.22967) \\
\end{array}$ & $\begin{array}{l}-0.17502 \\
(-0.35486, \\
0.00107) \\
\end{array}$ \\
\hline SBI(-3) & $\begin{array}{l}0.52557 \\
(0.32792 \\
0.71510)\end{array}$ & $\begin{array}{l}-0.31489 \\
(-0.50849, \\
-0.11276)\end{array}$ & $\begin{array}{l}-0.07255 \\
(-0.27207, \\
0.11723)\end{array}$ & $\begin{array}{l}0.24274 \\
(0.06492, \\
0.43934)\end{array}$ & $\begin{array}{l}-0.12510 \\
(-0.31733, \\
0.08352)\end{array}$ & $\begin{array}{l}-0.90687 \\
(-1.09397 \\
-0.73154)\end{array}$ \\
\hline GDP(-1) & $\begin{array}{c}0.16276 \\
(-0.03335 \\
0.35175) \\
\end{array}$ & $\begin{array}{l}-0.01294 \\
(-0.20422, \\
0.16736) \\
\end{array}$ & $\begin{array}{l}0.03744 \\
(-0.15677, \\
0.25887)\end{array}$ & $\begin{array}{l}0.01180 \\
(-0.18717, \\
0.19169)\end{array}$ & $\begin{array}{l}-0.03478 \\
(-0.25388, \\
0.17047)\end{array}$ & $\begin{array}{l}0.34961 \\
(0.17840 \\
0.54553)\end{array}$ \\
\hline GDP(-2) & $\begin{array}{l}0.09073, \\
(-0.10004, \\
0.28492)\end{array}$ & $\begin{array}{l}0.02826 \\
(-0.15724, \\
0.21127)\end{array}$ & $\begin{array}{l}-0.01851 \\
(-0.22190, \\
0.18302)\end{array}$ & $\begin{array}{l}-0.02682 \\
(-0.25413, \\
0.18722)\end{array}$ & $\begin{array}{l}-0.00322 \\
(-0.20491, \\
0.21083)\end{array}$ & $\begin{array}{l}-0.84901 \\
(-1.04340 \\
-0.64974)\end{array}$ \\
\hline GDP(-3) & $\begin{array}{l}0.17628 \\
(-0.00029, \\
0.36557)\end{array}$ & $\begin{array}{l}0.09250 \\
(-0.07733, \\
0.30240)\end{array}$ & $\begin{array}{l}0.03996 \\
(0.15348 \\
0.23479)\end{array}$ & $\begin{array}{l}0.03016 \\
(-0.15751, \\
0.20170)\end{array}$ & $\begin{array}{l}0.01277 \\
(-0.17830, \\
0.19301)\end{array}$ & $\begin{array}{l}0.35490 \\
(0.16581 \\
0.53612)\end{array}$ \\
\hline
\end{tabular}


From the result of parameter estimation of BVECM in Table 4, the model of BVECM(3) can be formed following the equation (1), $\Delta \boldsymbol{Y}_{t}=\prod \boldsymbol{Y}_{t-1}+\boldsymbol{\Gamma}_{1} \Delta \boldsymbol{Y}_{t-1}+\cdots+\boldsymbol{\Gamma}_{p} \Delta \boldsymbol{Y}_{t-p+1}+\boldsymbol{\varepsilon}_{t}$. The model of BVECM(3) is as follows.

$$
\begin{aligned}
{\left[\begin{array}{l}
\Delta Y_{1, t} \\
\Delta Y_{2, t} \\
\Delta Y_{3, t} \\
\Delta Y_{4, t} \\
\Delta Y_{5, t} \\
\Delta Y_{6, t}
\end{array}\right]=\left[\begin{array}{cccccc}
0.00299 & -0.00473 & -0.00314 & 0.00116 & -0.00568 & 0.00093 \\
-0.00094 & 0.00431 & 0.00250 & 0.00073 & -0.00276 & -0.00224 \\
-0.00049 & -0.00278 & 0.00525 & 0.00525 & -0.00925 & -0.00175 \\
-0.00195 & 0.00595 & 0.00724 & -0.00283 & -0.00082 & -0.00366 \\
-0.00098 & -0.01287 & 0.00462 & 0.00281 & -0.00037 & 0.00439 \\
0.00222 & -0.00487 & 0.00254 & 0.00085 & 0.00448 & -0.00202
\end{array}\right]\left[\begin{array}{l}
y_{1, t-1} \\
y_{2, t-1} \\
y_{3, t-1} \\
y_{4, t-1} \\
y_{5, t-1} \\
y_{6, t-1}
\end{array}\right] } \\
+\left[\begin{array}{ccccccc}
0.44656 & -0.01586 & -2.36228 & -3.46184 & -0.81032 & 0.16276 \\
-0.15488 & 0.33231 & 0.41315 & 0.6039 & 0.66499 & -0.01294 \\
0.06494 & -0.01492 & -0.37965 & -0.04386 & -0.34653 & 0.0374 \\
-0.05705 & -0.04411 & 0.09503 & -0.13968 & 0.28913 & 0.01180 \\
0.03862 & 0.04168 & 0.03830 & -0.25792 & 0.3700 & -0.03478 \\
0.31995 & 0.06384 & 2.77817 & 4.23834 & 0.10985 & 0.34961
\end{array}\right]\left[\begin{array}{l}
\Delta Y_{1, t-1} \\
\Delta Y_{2, t-1} \\
\Delta Y_{3, t-1} \\
\Delta Y_{4, t-1} \\
\Delta Y_{5, t-1} \\
\Delta Y_{6, t-1}
\end{array}\right] \\
+\left[\begin{array}{ccccccc}
0.22197 & -0.07083 & 0.49699 & 0.32914 & -0.28764 & 0.09073 \\
-0.04855 & 0.01368 & -1.11404 & -0.59287 & 0.74682 & 0.02826 \\
-0.00061 & -0.06759 & 0.27643 & 0.22459 & 0.01075 & -0.01851 \\
0.02832 & 0.06094 & -0.41878 & -0.13464 & 0.28269 & -0.02682 \\
-0.07320 & -0.15033 & 0.05945 & 0.05839 & 0.02915 & -0.00322 \\
0.00585 & -0.00439 & 0.05945 & -0.13352 & -0.17502 & -0.84901
\end{array}\right]\left[\begin{array}{l}
\Delta Y_{1, t-2} \\
\Delta Y_{2, t-2} \\
\Delta Y_{3, t-2} \\
\Delta Y_{4, t-2} \\
\Delta Y_{5, t-2} \\
\Delta Y_{6, t-2}
\end{array}\right] \\
+\left[\begin{array}{ccccccc}
0.16516 & 0.58104 & -0.25306 & -0.17728 & 0.52557 & 0.17628 \\
0.05944 & -0.18406 & -0.19282 & -0.17519 & -0.31489 & 0.09250 \\
-0.00620 & -0.11092 & 0.49351 & 0.48054 & -0.07255 & 0.03996 \\
0.01334 & 0.17554 & -0.36556 & -0.15111 & 0.24274 & 0.03016 \\
0.08198 & 0.1304 & -0.30917 & -0.16643 & -0.12510 & 0.01277 \\
0.11278 & -0.39161 & 2.45771 & 3.24043 & -0.90687 & 0.35490
\end{array}\right]\left[\begin{array}{l}
\Delta Y_{1, t-3} \\
\Delta Y_{2, t-3} \\
\Delta Y_{3, t-3} \\
\Delta Y_{4, t-3} \\
\Delta Y_{5, t-3} \\
\Delta Y_{6, t-3}
\end{array}\right]+\left[\begin{array}{l}
\varepsilon_{1, t} \\
\varepsilon_{2, t} \\
\varepsilon_{3, t} \\
\varepsilon_{4, t} \\
\varepsilon_{5, t} \\
\varepsilon_{6, t}
\end{array}\right]
\end{aligned}
$$

The next step in the BVECM approach is to test the convergence of the estimated parameters. The convergence can be seen by looking at the trace plot and density plot between the observations that have been generated. One of the trace plots of this research model is as follows.

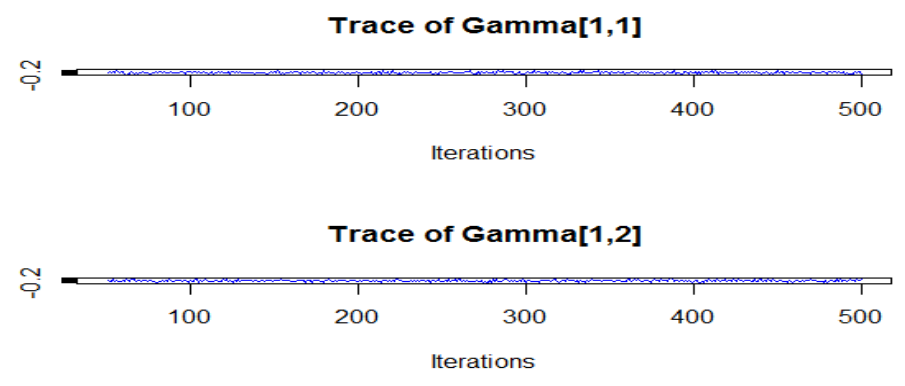

Figure 1. Trace Plot of Several BVECM Parameter Estimators

In Figure 1, it can be seen that the trace plot does not form a regular pattern when 500 iterations are carried out. It can be said that the random sample has converged and the iteration has stopped. Next, look at the posterior distribution for BVECM parameters. The posterior distribution formed from the predicted parameter variables can be seen from the kernel density (Ntzoufras, 2009). Some of the resulting posterior distributions are as follows. 
Density of Gamma[1,1]

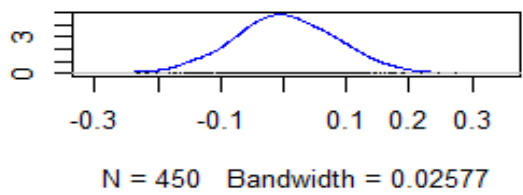

Density of Gamma[1,2]

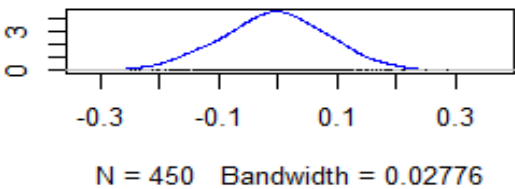

Figure 2. Density Plot of Several BVECM Parameter Estimators

Figure 2 shows that the posterior distribution formed for several parameters is in the form of a normal distribution. This indicates that the model parameters have converged. Based on the convergence test of the trace plot and density plot, it can be concluded that the assumed model has met the convergence criteria.

Then, the next step is diagnostic model test, which is to test the feasibility of the model. Diagnostic model tests performed on the VECM model are normality of the residual and non-autocorrelation of the residual. First, the residual normality test was carried out using the Jarque-Bera test using the skewness and kurtosis values (Lutkepohl, 2007).

Table 5. Residual Normality Test Results

\begin{tabular}{ccc}
\hline Test & Skewness/kurtosis Value & p-value \\
\hline Skewness & 35.92 & 0.98 \\
Kurtosis & -1.64 & 0.1 \\
\hline
\end{tabular}

Table 5 shows that the $\mathrm{p}$-value of multivariate skewness and multivariate kurtosis $>\alpha(0.05)$ so accept $\mathrm{H}_{0}$. That is, with a confidence level of $95 \%$ there is sufficient evidence to state that the residual is a multivariate normal distribution. Second, the residual non-autocorrelation test is done by the Portmanteau test or the Ljung Box Test. Table 6 shows the results of the residual non-autocorrelation test.

Table 6. Residual Autocorrelation Test Results

\begin{tabular}{|c|c|c|c|c|}
\hline \multicolumn{5}{|c|}{ Ljung-Box Statistics: } \\
\hline & $\mathrm{m}$ & $\mathrm{Q}(\mathrm{m})$ & $\mathrm{df}$ & p-value \\
\hline$[1]$, & 1.0 & 15.6 & 36.0 & 1.00 \\
\hline$[2]$, & 2.0 & 47.8 & 72.0 & 0.99 \\
\hline$[3]$, & 3.0 & 72.2 & 108.0 & 1.00 \\
\hline$[4]$, & 4.0 & 102.2 & 144.0 & 1.00 \\
\hline$[5]$, & 5.0 & 133.4 & 180.0 & 1.00 \\
\hline$[6]$, & 6.0 & 178.8 & 216.0 & 0.97 \\
\hline$[7]$, & 7.0 & 203.7 & 252.0 & 0.99 \\
\hline$[8]$, & 8.0 & 240.7 & 288.0 & 0.98 \\
\hline$[9]$, & 9.0 & 282.4 & 324.0 & 0.95 \\
\hline$[10]$, & 10.0 & 323.5 & 360.0 & 0.92 \\
\hline
\end{tabular}

The $\mathrm{p}$-value of the Ljung Box Test listed in Table 6 is more than $\alpha(0.05)$, concludes to accept $\mathrm{H}_{0}$, which means that the residual has no serial correlation. From the two model diagnostic test results, it shows that the model is feasible and can be used for forecasting.

\section{Discussion}

Based on Table 4, the variables which are significantly affecting GDP are GDP one to three previous quarters, the money supply in the previous quarter, exchange rate of rupiah to US Dollar in the previous third quarter, exports in the previous second quarter, imports in the previous first and third quarters and interest rates in the previous third quarter. The coefficient of the money supply is positive, which means that the relationship between the money supply and GDP is positive. This is relevant to the research of Asnawi \& Fitria (2018); Chaitip, et al (2015); and He (2017). The more the money supply increases, the public will put a portion of the funds for consumption, resulting that producers to produce more goods. Then production demand will increase. This will affect GDP and economic growth will increase. The coefficient of exchange rate of rupiah to US Dollar and exports is positive, so the relationship between exchange 
rate of rupiah to US Dollar and exports to GDP is positive. The relationship between exchange rate of rupiah to US Dollar, exports and GDP is mutually sustainable. This is in accordance with what is explained by Machmud (2016) and research by Rangkuty, Efendi, Nasution, \& Novalina (2019) and Ismanto, Rina, \& Kristini (2019) that the depreciation of the rupiah in theory can increase exports, causing an increase in production volume. The increase in exports of certain commodities indicates that the weakening of the exchange rate of rupiah to US Dollar has a positive effect on exports. The development of exports occurred due to the large depreciation of the rupiah causing exporters to be more interested in selling products on the international market than in the domestic market. Therefore, as exports increase, GDP also increases. In addition, this is also in accordance with the keynesian theory of the equation $\mathrm{Y}=\mathrm{C}+\mathrm{G}+\mathrm{I}+$ (X-M) that an increase in exports will increase GDP (Mankiw, 2009) and similar to the research findings of (Nugroho, 2014; Udin \& Khanam, 2017). The import coefficient of the first and third quarters was positive, so the relationship between imports and GDP was positive. This is the same as the research results of Ebrahimi (2017) that imports have a positive and significant effect on GDP. On the other hand, the Keynesian theory, imports will reduce Y or GDP as indicated by the import coefficient in the previous second quarter. However, Nehen (2010) and Pugel, Lindert, Pugel, \& Lindert (1999) provide an opinion that in the long run, if a country prioritizes imports of capital goods that support the process of producing goods for export purposes, it will have a positive impact on the country economic growth. Bank Indonesia Certificate interest rates affect GDP, which is in accordance with research results of Ar (2019) that interest rates have an influence on economic growth.

Macroeconomic variables that affect GDP are also influenced by other variables. The money supply was significantly influenced by the money supply in the first and two previous quarters, exchange rate of rupiah to US Dollar in the previous third quarter, exports in the previous one to three quarters, imports in the previous one to three quarters, interest rates in the previous one to three quarters and GDP in the previous third quarter. The exchange rate of rupiah to US Dollar variable was significantly affected by exchange rate of rupiah to US Dollar in the previous first quarter, exports in the previous one to three quarters, imports in the previous one to two quarters and interest rates in the previous one to three quarters. Meanwhile, the variables of money supply and GDP do not affect exchange rate of rupiah to US Dollar. The variables that significantly affect exports are exports in the first to three previous quarters, imports in the previous two to three quarters, and interest rates in the previous first quarter. Meanwhile, the variables of the money supply, exchange rate of rupiah to US Dollar and GDP do not affect exports. The variables that significantly affect imports are exports in the previous two and three quarters and interest rates in the previous one to three quarters. On the other hand, the variables of the money supply, exchange rate of rupiah to US Dollar and GDP do not affect imports. The interest rate variable for Bank Indonesia Certificates was significantly influenced by interest rates in the previous first quarter, exports in the previous third quarter and imports in the preceding quarter. On the other hand, the variables of the money supply, exchange rate of rupiah to US Dollar and GDP do not affect the variable interest rate for Bank Indonesia Certificates.

The value of Error Correction Term (ECT) in $\operatorname{BVECM}(3)$ for all insignificant variables is shown from the credible interval containing zero values. For example, the ECT1 GDP interpretation is 1,002 which is obtained from the exponential of 0.00222 , which shows that the amount of adjustment rate to achieve equilibrium from the short to the long term if there is a deviation will be corrected by 1.002 percent. This means that the long-term cointegration relationship in determining GDP in Indonesia is very small (Gujarati \& Porter, 2009).

Based on the diagnostic test results of the $\operatorname{BVECM}(3)$, the model meets the residual multivariate normality assumptions and the residual non-autocorrelation. Therefore, the $\operatorname{BVECM}(3)$ is feasible for forecasting. This study only presenting the parameter estimation results of the $\operatorname{BVECM}(3)$ for the relationship between macroeconomic variables in Indonesia. Therefore, in future research, forecasting for the relationship of macroeconomic variables can be added and further analysis such as Impulse Response Function and Variance Decomposition.

\section{Conclusion}

This study uses VECM analysis with a Bayesian approach to analyzing the relationship between macroeconomic variables in Indonesia. To estimate parameters, it uses the Gibbs Sampler simulation with the iteration of 500 samples to get convergent results. The appropriate model is the $\operatorname{BVECM}(3)$ which has been proven that the model is suitable from the model diagnostic test (residual normality and residual non-autocorrelation). This conclusion is relevant to the statement that the Bayesian method can solve the problem of overparameterization. So, the BVECM(3) is suitable for forecasting in future studies.

From the parameter estimation results of BVECM(3), the variables which are significantly affecting GDP are GDP itself, the money supply, exchange rate of rupiah to US Dollar, exports, imports and the interest rate for Bank Indonesia Certificates. These variables also have a two-way relationship, namely the relationship between GDP and the money supply, exports and imports, exports and interest rates, and between imports and interest rates. 


\section{Acknowledgments}

The author would like to thank the thesis supervisors who have provided guidance, direction and input in completing this research. In addition, the authors would like to thank the Ministry of Research, Technology, and Higher Education of the Republic of Indonesia for providing the 2020 master thesis grant to facilitate this research.

\section{References}

Amzal, C. (2016). The Impact of Macroeconomic Variables on Indonesia Islamic Banks Profitability. JEBIS (Jurnal Ekonomi Dan Bisnis Islam), 2(1), 71-86.

Ar, M. Y. (2019). The Effect of Inflation, Exchange Rates and Interest Rates on Economic Growth. JURNAL EKOMBIS, $5(1), 38-45$.

Asnawi, \& Fitria, H. (2018). The Effect of Money Supply, Interest Rates nd Inflation on Economic Growth in Indonesia. Jurnal Ekonomika Indonesia, 7(1), 24-32.

Basuki, A. T., \& Prawoto, N. P. (2018). The Effect of Macroeconomic Variables on Indonesia Trade (VECM Approach). Buletin Ekonomi Manajemen, Ekonomi Pembangunan, Akuntansi, 16(2), 147-158.

Byrne, B. M. (2013). Structural Equation Modeling With Lisrel, Prelis, and Simplis: Basic Concepts, Applications, and Programming. New York: Psychology Press. https://doi.org/10.4324/9780203774762

Chaitip, P., Chokethaworn, K., Chaiboonsri, C., \& Khounkhalax, M. (2015). Money Supply Influencing on Economic Growth-wide Phenomena of AEC Open Region. Procedia Economics and Finance, 24, 108-115. https://doi.org/10.1016/S2212-5671(15)00626-7

Cryer, J. D., \& Chan, K. (2008). Time Series Analysis: With Applications in $R$ (2nd ed). New York: Springer. https://doi.org/10.1007/978-0-387-75959-3

Ebrahimi, N. (2017). An Analysis of the Relationship of Imports and Economic Growth in Iran (Comparison of Systematic and Unsystematic Cointegration Methods with Neural Network). International Journal of Economics and Financial Issues, 7(2), 338-347.

Enders, W. (2015). Applied Econometric Time Series (Fourth edition). Hoboken, NJ: Wiley.

Esen, Ö., \& Bayrak, M. (2017). Does more energy consumption support economic growth in net energy-importing countries. Journal of Economics, Finance and Administrative Science, 22(42), 75-98. https://doi.org/10.1108/JEFAS-01-2017-0015

Gujarati, D. N., \& Porter, D. C. (2009). Basic econometrics (5th ed). Boston: McGraw-Hill Irwin.

He, Y. (2017). A Study on the Relationship between Money Supply and Macroeconomic Variables in China. Mediterranean Journal of Social Sciences, 8(6), 99-107. https://doi.org/10.1515/mjss-2017-0046

Ismanto, B., Rina, L., \& Kristini, M. A. (2019). The Effect of Exchange Rates and Imports on Indonesia's Economic Growth in 2007-2017. Forum Ekonomi, 20(1), 1-6.

Karlsson, S. (2013). Forecasting with Bayesian Vector Autoregressions. 105. https://doi.org/10.1016/B978-0-444-62731-5.00015-4

Lutkepohl, H. (2005). New Introduction to Multiple Time Series Analysis. Berlin: New York: Springer. https://doi.org/10.1007/978-3-540-27752-1

Lutkepohl, H. (2007). Econometric Analysis with Vector Autoregressive Models [Working Paper]. European University Institute. Retrieved from European University Institute website: http://cadmus.eui.eu//handle/1814/6918

Machmud, A. (2016). Post Reform's Indonesian Economy. Jakarta: Erlangga.

Mankiw, N. G. (2009). Principles of Macroeconomics (Fifth edition). Mason, OH: South-Western, Cengage Learning.

Nehen, K. (2010). Indonesian Economy. Denpasar: Udayana University Press. Retrieved from http://library.um.ac.id/free-contents/index.php/buku/detail/perekonomian-indonesia-ketut-nehen-40936.html

Ntzoufras, I. (2009). Bayesian Modeling Using WinBUGS. Hoboken, N.J: Wiley. https://doi.org/10.1002/9780470434567

Nugroho, P. A. (2014). Analysis of Exports, Exchange Rates, and Interest Rates on Indonesia's Gross Domestic Product for the Years 1970-2013. Universitas Muhammadiyah Yogyakarta, 1-22.

Pereira, F. (1999). Practical “Modern” Bayesian Statistics in Actuarial Science. General Insurance Convention, $164-199$. 
Pugel, T. A., Lindert, P. H., Pugel, T., \& Lindert, P. (1999). International Economics (11th edition). Boston: Mcgraw-Hill College.

Rangkuty, D. M., Efendi, B., Nasution, L. N., \& Novalina, A. (2019). The Analysis Export Trend of Indonesia to ASEAN Countries. Journal of Economics and Finance, 10(5), 23-31.

Sinay, L. J. (2014). Vector Error Correction Model approach for Analysis of the Relationship between Inflation, BI rate and the United States Dollar Exchange Rate. BAREKENG: Jurnal Ilmu Matematika dan Terapan, 8(2), 9-18. https://doi.org/10.30598/barekengvol8iss2pp9-18

Syed, A. A. S. G., \& Shaikh, F. M. (2013). Effects of Macroeconomic Variables on Gross Domestic Product (GDP) in Pakistan. Procedia Economics and Finance, 5, 703-711. https://doi.org/10.1016/S2212-5671(13)00082-8

Tahir, M. A. (2014). Analyzing and Forecasting Output Gap and Inflation Using Bayesian Vector Auto Regression (BVAR) Method: A Case of Pakistan. International Journal of Economics and Finance, 6(6), 10. https://doi.org/10.5539/ijef.v6n6p257

Udin, H., \& Khanam, J. (2017). Import, Export and Economic Growth: The Case of Lower Income Country. Journal of Business and Management, 19(1), 37-42. https://doi.org/10.9790/487X-1901053742

Verbeek, M. (2017). A Guide to Modern Econometrics (5th edition). Hoboken, NJ: John Wiley \& Sons, Inc.

Villani, M. (2005). Bayesian Reference Analysis of Cointegration. 21, 326-357. https://doi.org/10.1017/S026646660505019X

\section{Copyrights}

Copyright for this article is retained by the author(s), with first publication rights granted to the journal.

This is an open-access article distributed under the terms and conditions of the Creative Commons Attribution license (http://creativecommons.org/licenses/by/4.0/). 